\title{
An alternative for one lung ventilation in an adult horse requiring thoracotomy
}

\author{
Een alternatief voor de ventilatie van één long tijdens \\ thoracotomie bij een volwassen paard
}

\author{
${ }^{1}$ M. Gozalo-Marcilla, ${ }^{1}$ S. Schauvliege, ${ }^{2}$ S. Torfs, ${ }^{1}$ M. Jordana, ${ }^{1}$ A. Martens, ${ }^{1}$ F. Gasthuys \\ ${ }^{1}$ Department of Surgery and Anesthesia of Domestic Animals, Faculty of Veterinary Medicine, Ghent \\ University, Salisburylaan 133, B-9820 Merelbeke, Belgium \\ ${ }^{2}$ Department of Large Animal Internal Medicine, Faculty of Veterinary Medicine, University of Ghent, \\ Salisburylaan 133, B-9820 Merelbeke, Belgium
}

miguelgozalomarcilla@UGent.be

\begin{abstract}
In order to provide one lung ventilation in an anesthetized adult horse undergoing thoracoscopy and exploratory thoracotomy, an alternative to the described techniques was developed using a homemade endobronchial blocker construction. An orifice (with a diameter of $1 \mathrm{~cm}$ ) was made $15 \mathrm{~cm}$ distally to the proximal end of a standard $28 \mathrm{~mm}$ ID endotracheal tube (ETT) allowing the placement of a standard broncho-alveolar catheter. The adapted ETT was advanced up to the larynx in the anesthetized horse. Prior to the intubation of the trachea, the broncho-alveolar catheter was passed through the ETT and positioned into the left main bronchus under endoscopic guidance. If it would have been required, the cuff of the broncho-alveolar catheter could have been inflated, allowing OLV. However, one lung ventilation was not required during the surgical procedure.
\end{abstract}

\section{SAMENVATTING}

Om één long van een volwassen paard te kunnen ventileren tijdens de anesthesie voor een thoracoscopie en exploratieve thoracotomie, werd met behulp van een zelfgemaakte endobronchiale blocker een andere dan de gerapporteerde technieken ontwikkeld. Een opening met een diameter van $1 \mathrm{~cm}$ werd gemaakt $15 \mathrm{~cm}$ distaal van het proximale uiteinde van een standaard $28 \mathrm{~mm}$ ID endotracheale tube (ETT), waar een broncho-alveolaire katheter kon doorgeschoven worden. Na inductie van de anesthesie werd de aangepaste ETT opgeschoven tot aan de larynx. Vóór de intubatie van de trachea werd de broncho-alveolaire katheter opgeschoven door de ETT en onder endoscopische begeleiding in de linkerhoofdbronchus geplaatst. Alhoewel dit niet nodig bleek tijdens de chirurgische ingreep, zou het volstaan hebben de cuff van de broncho-alveolaire katheter op te blazen om op de ventilatie van één long over te schakelen.

\section{INTRODUCTION}

Double-lumen tubes or bronchial blocking devices to perform one lung ventilation (OLV) are not commercially available for horses. Double-lumen tubes have been developed using an endobronchial double-lumen tube (Elliot and Steffey, 1988) or a tracheal divider (Stolk, 1980; McDonell, 1974) via tracheotomy. The tracheal 'tube-in-tube' technique has been described for the functional separation of the lungs without tracheotomy (Moens et al., 1992). More recently, Bauquier et al. (2010) performed OLV in a horse undergoing pulmonectomy with a customized tube via tracheotomy.

This communication describes an alternative to these techniques.

\section{CASE DESCRIPTION}

A four-year-and-seven-months-old, female warmblood of $580 \mathrm{~kg}$ underwent a thoracoscopy under general anesthesia to determine the cause of a pleural ef- fusion. The horse had been anesthetized six days earlier for surgical debridement and exploration of a wound of the thoracic wall at the level of the left shoulder.

A homemade tracheal tube was constructed to perform OLV (Figures 1 and 2). An orifice with a diameter of $1 \mathrm{~cm}$ was made $15 \mathrm{~cm}$ distally to the proximal end of a standard $28 \mathrm{~mm}$ ID silicone Cook endotracheal tube (ETT). Using this orifice, a commercial silicone broncho-alveolar (BAL) catheter with cuff (Cook Veterinary Products, V-PBAL-240) was passed inside the ETT. The BAL catheter had the function of an endobronchial blocker (EBB).

Once anesthetized, the horse was transported to a surgical table and positioned in right lateral recumbency. Initially, anesthesia was maintained with total intravenous anesthesia ('triple drip') to allow the placement of the adapted ETT. Under endoscopic (ETM Endoscopische Technik GmbH, Germany) guidance via the nose, the ETT with the BAL catheter inserted through the proximal orifice was advanced until the la- 


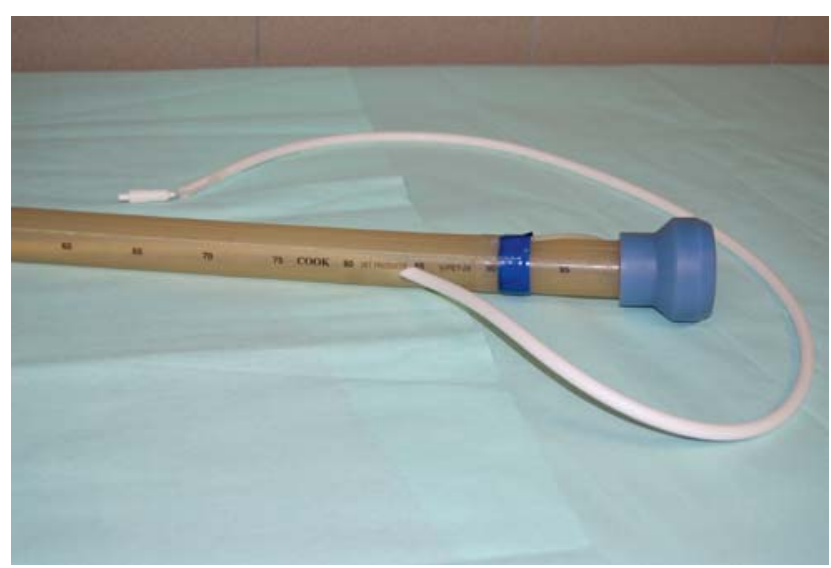

Figure 1. Proximal end of the homemade tracheal tube. An orifice with a diameter of $1 \mathrm{~cm}$ was made $15 \mathrm{~cm}$ distally to the proximal end of a standard $28 \mathrm{~mm}$ ID silicone Cook tube. Using this orifice, a commercial broncho-alveolar catheter with cuff was passed inside the endotracheal tube.

rynx. Then the BAL catheter was advanced into the trachea and positioned into the left bronchus using endoscopic guidance, and the cuff of this BAL catheter was inflated to secure its position. Tracheal intubation was performed afterwards by sliding the ETT over the BAL catheter. The total time for the EBB placement and endotracheal intubation was 10 minutes. Finally, the correct position of both tubes was confirmed endoscopically via the nose. The cuff of the BAL catheter was then deflated and ready to use if required and the proximal (free) end of the BAL was sealed with a bung to avoid leakage of anesthetic gases.

The ETT was connected to a large animal anesthetic unit (Matrx medical Inc., Orchard Park, NY, USA mounted on a Sulla 909V; Dräger, Germany) with an out-of-circuit vaporizer (Drägerwerk AG) and a large animal ventilator (Smith respirator LA 2100; model 2002, Veterinary Technics/BDO-Medipass, The Netherlands). The hole between the BAL catheter and the ETT was sealed with tape to avoid leakage.

Anesthesia was maintained using isoflurane (Isoflo, Abbott Laboratories Ltd., UK) in oxygen and a romifidine (Sedivet, Boehringer Ingelheim, Belgium) infusion for 210 minutes. Intermittent positive pressure ventilation (IPPV) was initiated (assisted-controlled mode, tidal volume $\left(\mathrm{V}_{\mathrm{T}}\right)$ of $10 \mathrm{~mL} / \mathrm{kg}$, peak inspiratory pressure of $30 \mathrm{cmH}_{2} \mathrm{O}$, inspiratory time of 2.2 seconds and respiratory rate of $10-12$ breaths/minute). Positive end expiratory pressure (PEEP) $\left(10 \mathrm{cmH}_{2} \mathrm{O}\right)$ was also applied using a homemade plastic cylinder filled with $10 \mathrm{~cm}$ of water. Lactated Ringer's solution (10 $\mathrm{mL} / \mathrm{kg} /$ hour, Ringer Lactate, Vetoflex, Bioluz, France) was used for fluid therapy.

Monitoring included electrocardiography, invasive blood pressure, capnography, inspiratory and expiratory carbon dioxide $\left(\mathrm{CO}_{2}\right)$, oxygen, isoflurane and pulse oximetry.

Arterial blood gases were analysed every 15 minutes.

Moderate hypotension was treated with dobutamine (Dobutamine EG, NV Eurogenerics, Belgium).

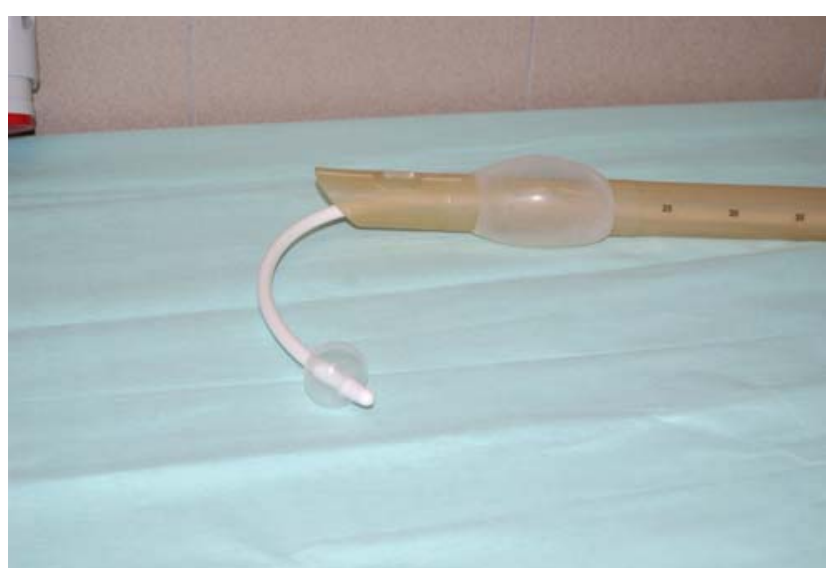

Figure 2. Distal end of the homemade tracheal tube. The broncho-alveolar catheter can be inflated until a diameter of 30-35 mm if one lung ventilation would be required.

Arterial partial pressure of oxygen $\left(\mathrm{PaO}_{2}\right)$ and hemoglobin saturation $\left(\mathrm{SpO}_{2}\right)$ slightly decreased and $\mathrm{PaCO}_{2}$ slightly increased at the beginning and at the end of the anesthesia. No other anesthetic complications were present.

Thoracoscopy revealed the presence of fibrin in the left hemithorax; a thoracotomy was performed. Pleuritis and communication with the right pleural cavity were confirmed. Induced collapse of the left lung was not required. Inflation of the cuff of the BAL catheter and adjustment of ventilator settings would have been sufficient to allow OLV.

Recovery from anesthesia (assisted with ropes) was uneventful.

\section{DISCUSSION}

A homemade tracheal device was constructed to perform OLV without the need of a tracheotomy in an adult horse undergoing a thoracoscopy/thoracotomy. Although OLV was not required, inflation of the cuff of the EBB would have produced collapse of the left lung.

Several options to perform OLV in horses were considered before anesthesia. Bauquier et al. (2010) instituted OLV in an adult horse by using a customized 'tube-in-tube' bronchial blocker, although tracheotomy was needed. Selective intubation of the right pulmonary bronchus was a second possibility, but a tracheotomy still would have been required. Due to their invasiveness, both of these options were excluded.

Moens et al. (1992) described a double-lumen tube for adult horses, avoiding tracheotomy. For the intubation, endoscopic guidance is essential. With the cuff of the outer tube in the trachea and the cuff of the inner tube in the left bronchus, both lungs are ventilated at the same time by connecting the outer tube to the ventilator and inflating its cuff. Ventilation of the right lung is achieved by inflation of the cuffs of the outer and inner tubes and the connection of the outer tube to the ventilator. Ventilation of the left lung is achieved by the connection of the inner tube to the ventilator and in- 
flation of the cuff of the inner tube exclusively. In comparison, the technique described in the present case allows ventilation of both lungs or the selective ventilation of the right lung, but not the ventilation of the left lung (where the EBB is placed). However, during OLV, the resistance would be lower than with the technique of Moens et al. (1992), where the diameter of the inner tube was larger than that of the BAL catheter in the present case.

In the present case, endoscopic guidance was used to assure the correct placement of the BAL catheter as an EBB and to avoid blockage of the left apical lobe bronchus. Data on bronchial anatomy in horses from Moens et al. (1992) were used as a guideline. The introduction of the endoscope through the ETT and the placement of a BAL catheter after endotracheal intubation were avoided due to the limited space to handle both devices and due to the reduction of the airway patency. The placement of the ETT and the positioning of the EBB were performed without problems using a standard 'triple drip'. The diameter of the BAL catheter cuff was large enough to occlude the left bronchus, which has been reported to have a diameter of about 30 $\mathrm{mm}$ in the adult horse (Moens et al., 1992). Once the EBB was placed and the tracheal intubation was performed, correct positioning was again confirmed endoscopically and the standard ETT was connected to the anesthetic machine. With the EBB in place, OLV could have been achieved by inflating the cuff of the BAL catheter.

The displacement of the EBB after positioning might be a limitation of this technique. Moens et al. (1992) advised an adjustment/control of the EBB if a change in body position would occur. In the current case, the patient remained in right lateral recumbency. Hence, the EBB was assumed to be maintained in the same position.

Hypoxemia is a complication of OLV caused by ventilation/perfusion (V/Q) mismatch as documented in dogs (Kudnig et al., 2003). Hypoxic pulmonary vasoconstriction (HPV) is an important pathophysiologic mechanism during OLV, which may reduce venous admixture and limit the fall in $\mathrm{PaO}_{2}$ by diverting pulmonary blood flow from the non-ventilated to the ventilated lung areas (Abe et al., 1998). Inhalant anesthetics used for OLV inhibit HPV in a dose-dependent manner, increasing the intrapulmonary shunt fraction and reducing $\mathrm{PaO}_{2}$ in humans (Abe et al., 1998). The HPV response has been reported to be weaker in dogs than in swine and ponies being intermediate (Elliot et al., 1991).

To avoid hypoxemia, IPPV was applied in the present case. Caution should be taken because OLV with high $\mathrm{V}_{\mathrm{T}}$ results in reduced perfusion of the lung, leading to an increase in dead space fraction and $\mathrm{PaCO}_{2}$. Furthermore, OLV carries a risk of volutrauma because of high peak inspiratory pressure (Gama de Abreu et al., 2003). The increases in $\mathrm{PaCO}_{2}$ observed in patients under OLV have been reported to be concurrent with the early increase in V/Q mismatch (Cantwell et al., 2000). In the present case, the increases were controlled by adjusting the ventilation, based on blood gas monitoring. In the present horse, a degree of moderate hypercapnia was allowed.

During OLV, PEEP prevents desaturation and maintains the alveoli of the ventilated, dependent lung open (Lansdowne et al., 2005); it improves blood oxygenation and decreases shunt fraction in humans (Fujiwara et al., 2001). Negative hemodynamic effects of PEEP such as excessive airway pressure, which may decrease blood flow to the ventilated lung, (Lejeune et al., 1991) should be considered. However, in a study by Kudnig et al. (2003), OLV did not reduce the oxygen delivery index in dogs during open thoracic surgery and the use of PEEP did not seem to affect oxygen delivery and cardiac output in dogs during thoracoscopy (Riquelme et al., 2005). Although OLV was not required in the present case, a PEEP of $10 \mathrm{cmH}_{2} \mathrm{O}$ was applied due to possibly compromised pulmonary function. In the clinical treatment of arterial hypoxemia in colic horses, PEEP has been reported to be useful (Wilson and McFeely, 1991). Further studies in adult horses have shown that PEEPs of $10-20 \mathrm{cmH}_{2} \mathrm{O}$ increased $\mathrm{PaO}_{2}$, attribute to improved $\mathrm{V} / \mathrm{Q}$, especially in the dependent lung (Moens et al., 1998).

This report shows a cheap, non-invasive and easy to perform alternative to produce OLV in the horse. Although OLV was not required, inflation of the cuff of the EBB would have produced the collapse of the left lung and the ventilation of the right lung.

\section{ACKNOWLEDGEMENTS}

The authors would like to thank Nichola J. Martinez (nee Hayes) (from the Anwell Veterinary Centre, UK) for her critical reading of this case report.

\section{REFERENCES}

Abe K., Shimizu T., Takashina M., Shiozaki H., Yoshiya I. (1998). The effects of propofol, isoflurane and sevoflurane on oxygenation and shunt fraction during one-lung ventilation. Anesthesia and Analgesia 87, 1164-1169.

Bauquier S.H., Dusavage S., Driessen B. (2010). Anaesthesia and ventilation strategy in a horse undergoing pulmonectomy. Equine Veterinary Education 22, 231-236.

Cantwell S.L., Duke T., Walsh P.J., Remedios A.M., Walker D., Ferguson J.G. (2000). One-lung versus two-lung ventilation in the closed-chest anesthetized dog: a comparison of cardiopulmonary parameters. Veterinary Surgery 29, 365-373.

Elliot A.R., Steffey E.P. (1988). Double lumen tracheal tubes for differential lung ventilation in miniature swine and ponies. In: Proceedings $3^{\text {rd }}$ International Congress of Veterinary Anaesthesia, Brisbane, Australia.

Elliot A.R., Steffey E.P., Jarvis K.A., Marshall B.E. (1991). Unilateral hypoxic pulmonary vasoconstriction in the dog, pony and miniature swine. Respiration Physiology 85, 355-369.

Fujiwara M., Abe K., Mashimo T. (2001). The effect of positive end-expiratory pressure and continuous positive airway pressure on the oxygenation and shunt fraction during one-lung ventilation with propofol anesthesia. Journal of Clinical Anesthesia 13, 473-477.

Gama de Abreu M., Heintz M, Heller A., Széchényi R., Al- 
brecht D.M., Koch T. (2003). One-lung ventilation with high tidal volumes and zero positive end-expiratory pressure is injurious in the isolated rabbit lung model. Anesthesia and Analgesia 96, 220-228.

Kudnig S.T., Monnet E., Riquelme M., Gaynor J.S., Corliss D., Salman M.D. (2003). Effect of one-lung ventilation on oxygen delivery in anesthetized dogs with an open thoracic cavity. American Journal of Veterinary Research 64, 443-448.

Lansdowne J.L., Monnet E., Twedt D.C., Dernell W.S. (2005). Thoracoscopic lung lobectomy for treatment of lung tumors in dogs. Veterinary Surgery 34, 530-535.

Lejeune P., Vachiery J.L., DeSmet J.M. Leeman M., Brimioulle S., Delcroix M., Melot C., Naeije R. (1991). PEEP inhibits hypoxic pulmonary vasoconstriction in dogs. Journal of Applied Physiology 70, 1867-1873.

McDonell W.N. (1974). The effect of anaesthesia on pulmonary gas exchange and arterial oxygenation in the horse. PhD thesis, University of Cambridge, 75-77.

Moens Y., Gootjes P., Lagerweij E. (1992). A tracheal tubein-tube technique for functional separation of the lungs in the horse. Equine Veterinary Journal 24, 103-106.
Moens Y., Lagerweij E., Gootjes P., Poortman J (1998). Influence of tidal volume and positive end-expiratory pressure on inspiratory gas distribution and gas exchange during mechanical ventilation in horses positioned in lateral recumbency. American Journal of Veterinary Research 59, 307-312.

Riquelme M., Monnet E., Kudnig S.T. Gaynor J.S., Wagner A.E., Corliss D., Salman M.D. (2005). Cardiopulmonary effects of positive end-expiratory pressure during onelung ventilation in anesthetized dogs with a closed thoracic cavity. American Journal of Veterinary Research 66, 978-983.

Stolk P.W. (1980). The effect of anaesthesia on pulmonary blood flow in the horse. PhD thesis, University of Cambridge, 44-45.

Wilson D.V., McFeely A.M. (1991). Positive end-expiratory pressure during colic surgery in horses: 74 cases (19861988). Journal of the American Veterinary Medical Assocciation 199, 917-921.

Persbericht

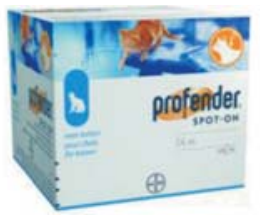

\section{Profender Cat Spot-on}

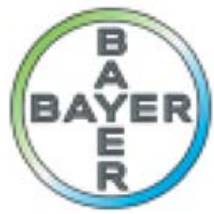

- Ontwormingsmiddel met breed en diep spectrum;

- Inhoud flacon + groothandelsprijs is identiek aan het totaal volume en prijs van een 20 pipetverpakking Profender Spot-on voor de middelgrote kat

- Met één flesje kunnen katten van alle gewichtsklassen behandeld worden;

- Toediening van de juiste dosering voor katten vanaf 8 weken en meer dan 0,5 kg.

Profender Spot-on oplossing voor katten $21,4 \mathrm{mg} / \mathrm{ml}$ emodepside en $\mathbf{8 5 , 8} \mathrm{mg} / \mathrm{ml}$ praziquantel Indicaties: Voor katten die lijden aan of het risico lopen op gemengde parasitaire infecties veroorzaakt door rondwormen en lintwormen van de volgende soorten: Rondwormen (nematoden): Toxocara cati (onvolgroeide en volwassen stadia, L4 en L3), Toxascaris leonina (onvolgroeide en volwassen stadia en L4), Ancylostoma tubaeforme (onvolgroeide en volwassen stadia en L4) en Lintwormen (cestoden): Dipylidium caninum (volwassen stadia), Taenia taeniaeformis (volwassen stadia), Echinococcus multilocularis (volwassen stadia). Contra-indicaties: Niet gebruiken bij kittens jonger dan 8 weken of van minder dan 0,5 kg. Bijwerkingen: In zeer zeldzame gevallen kunnen speekselen en braken optreden. Men veronderstelt dat dit zich voordoet tengevolge van likken aan de plaats van toediening door de kat onmiddellijk na de behandeling. In zeer zeldzame gevallen werd na toediening van Profender voorbijgaande alopecie, pruritus en/of ontsteking ter hoogte van de toedieningsplaats waargenomen. Dosering: De aanbevolen minimale dosis is $3 \mathrm{mg} / \mathrm{kg}$ lichaamsgewicht emodepside en $12 \mathrm{mg} / \mathrm{kg}$ lichaamsgewicht praziquantel, equivalent met $0,14 \mathrm{ml} / \mathrm{kg}$ lichaamsgewicht Profender. Een eenmalige toediening per behandeling is doeltreffend. 